\title{
School Banking:Concept, Contribution and Prospect: The Perspective of Dutch Bangla Bank Ltd. (DBBL)
}

\author{
Mousumi Sultana ${ }^{1} \quad$ Md. Julhaz Hossain ${ }^{2 *} \quad$ Mosa. Layla Arzuman Banu ${ }^{1}$ \\ 1.Lecturer, Department of Business Administration, Varendra University, Rajshahi-6204, Bangladesh \\ 2.Lecturer, Institute of Business Administration (IBA), University of Rajshahi, Rajshahi-6205, Bangladesh
}

\begin{abstract}
School Banking is significantly contributing in the financial inclusion of the students by providing them the opportunities to receive the privileged banking services designed and offered by the banks. The broad aim of school banking is to introduce the students with financial literacy and make them aware of modern banking facilities and bring them under umbrella of banking services that habituate the school going child with banking transaction so that the regular savings tendency may grow. Initially, Bangladesh Bank (BB) as the central bank of Bangladesh inaugurated the concept of school banking scheme and instructed all the scheduled banks to open and maintain the student accounts. Dutch Bangla Bank Ltd.(DBBL) like the other scheduled banks inaugurated the banking services specially for the school going students and contributed immensely to make the initiative successful. The purpose of the paper is to explain the related concepts of school banking and unveil its contribution and explore the emerging prospects in the years to come where DBBL has been considered as a case. The study collected the data from secondary sources while the consecutive four years' published annual reports of Bangladesh Bank, DBBL and BANBEIS were considered for the analysis. Trend analysis and descriptive statistics with the help of SPSS software and Microsoft excel were used to summarize and analyze the data. The paper resulted that DBBL performed well with positive growth though the rate of progress is slow. In line with this, the study forecasted an estimated upward trend in terms of account opening and deposit collection for future two years instead of having numerous existing barriers faced by DBBL. To ensure the smooth and rapid growth, Bangladesh bank along with all the stakeholders should emphasize on working together to promote the concept of banking for the students.

Keywords: school banking, financial inclusion, financial literacy, dutch bangla bank Ltd. (DBBL). DBBL school savers account, policy guideline of school banking.
\end{abstract}

DOI: $10.7176 / \mathrm{EJBM} / 12-6-09$

Publication date: February $29^{\text {th }} 2020$

\section{Introduction}

A mentionable part of the country's population is school going children. Besides civic education, hygiene knowledge and academic literacy, financial literacy is also important for a student (Bowman 1922). Scholastically, financial literacy means the knowledge and skills of managing money (Beverly \& Burkhalter 2005). Through this literacy, a student can be oriented to manage and save money for his/her higher education and for better future. Therefore, Bangladesh Bank (BB), The central bank of Bangladesh initiated school banking scheme by instructing all the scheduled banks of Bangladesh to promote the initiative in order to grow savings tendency and enhance the banking literacy among the school goers. As per the policy guideline of school banking and instructions issued by $\mathrm{BB}$, a student aging between six to below eighteen can open an account under school banking scheme with the consent and help of their parents. To comply the policy guideline of school banking, Dutch-Bangla Bank Limited (DBBL), a scheduled joint venture commercial bank in Bangladesh (Rana et al. 2012) started school banking scheme named DBBL school savers account in 2011 soon after the instruction of BB. Under this type of account, students can enjoy the regular banking services like depositing, withdrawal and other banking services without any bank fee or charges. In recent years, DBBL contributed significantly in exploring school banking initiatives. This bank collects the maximal amount of deposit among all the private commercial banks of Bangladesh by means of school banking scheme (Mondal, Hossain \& Khan 2015, Khan, Naim \& Begum 2017). In addition, by creating awareness and arranging school banking conference across the country, DBBL is now contributing the economy by a giant amount of school banking deposit. Though the deposit collected from the school goers seems miniature in nature, this small effort can play a major role in economic development as the banks offer loans to the borrower i.e entrepreneurs, business and companies etc. for funding the projects through collected deposit of school banking scheme. Hence, school banking as a part of inclusive financial system in the economy enables the students to be discreet in money management, financially empowered; a student can contribute in attaining the long term development of the economy.

\section{Literature Review}

School banking concept was begun for the first time with the earliest school savings bank named Goshar at Germany in 1820 (Sarker \& Foysal 2018). Likewise, the banking for the students started in late 1870s in America and in the 1960s in Bangladesh (Khan, Naim \& Begum 2017). But a clear understanding and the study of this 
concept was launched to emerge in Bangladesh since 2010 though the extant literature is very rare.

Mondal, Hossain \& Khan (2015) expatiated the school banking as an emerging concept of Bangladesh. As banks undertake different strategies to gather deposit, school banking account can be a great solution for this attempt. Their study showed that after the policy formulation of Bangladesh Bank regarding school banking, the scheduled banks were motivated to introduce school banking service in an appeasing way. The paper pointed the pioneer role of banks especially private commercial banks in opening more school bank accounts in Bangladesh.

Khan, Naim \& Begum (2017) stated the importance of school banking system for a developing economy like Bangladsh. In spite of being in the primary level of school banking service, it started gaining strong popularity among the school going children and their parents. Hence the emphasis must be given on promoting and developing the banking platform for the students by the concerned authority.

Sarker \& Foysal (2018) described how school banking could help in developing the small savings of the students and parents and also creating a savings tendency among the school going children. According to the study, about $78 \%$ clients of school banking service used their account on monthly basis and nearly $68 \%$ clients were paying their tuition fees through their account.

Rahman (2011) reported that, after the circular issued by Bangladesh Bank regarding school banking in November 2010, Eastern Bank Ltd. (EBL), a scheduled private bank in Bangladesh was the pioneer bank to introduce school banking concept named 'EBL Junior' account with the aim to include young generation under the banking umbrella. In addition, the report clarified that both the conventional and the Shariah based banks of Bangladesh felt interested in school banking whereas the intention of the banks was not to earn profit but to avail the chance of converting a school banking client into a regular profitable client in future.

Iraj (2018) emphasized that school banking started gaining huge popularity day by day among the students and guardians. As per the findings of the report, Bangladesh Bank (BB) received taka 13.63 billion deposit as a part of financial inclusion with 1,453,936 numbers of school bank accounts up to 31 st December 2017. The study included the interview of some school bank account holders and resulted that the students were saving money for higher study, tuition fees and future financial crisis.

Hasan (2018) tried to explore the true scenario of school banking scheme through the quarterly report of Bangladesh Bank. According to the findings, the total number of 1,609,961 school bank accounts were generated by the 56 scheduled banks in Bangladesh till September 2018. More interestingly, the study found that school banking was more popular in cities having $61.40 \%$ school banking accounts of total. Besides, male students compared to female students were showing much interest in school banking holding $58.20 \%$ of total school banking accounts. The reason of the growing popularity was the attractive feature of school banking account like charge free banking service with a lucrative profit rate on deposits, internet banking, ATM facilities etc.

Chowdhury (2019) revealed that school banking became an amazing tool for students' financial inclusion in Bangladesh. In this regard, Bangladesh Bank (BB) placed a great effort to boost up the initiative. Furthermore, the report unveiled that Bangladesh Bank was taking the help of a group of nominated lead banks to track the activities of school banking. Then, those selected lead banks were working in every district of Bangladesh, arranging conferences, preparing reports and also setting a minimum account opening targets for the banks to heighten the growth of school banking. Additionally, the report resulted that the total deposit of school banking was Tk 15.46 billion around the end of the March, 2019.

Islam (2019) described that school banking which became a strong component to ensure inclusive growth, started getting positive responses from the population of Bangladesh. The paper focused that a child could be aware of savings from childhood and hence the savings tendency might develop. The school banking provided an opportunity for the students to be oriented with the modern monetary transaction procedure through proper banking channel. Therefore, the economy as a whole with students' savings and banking knowledge will be affected gradually in a positive manner.

Mondal, Hossain \& Khan (2015) showed that financial inclusion depends on financial awareness, acquaintance with financial services and benefits and increasing financial literacy among the people. To broaden the term financial inclusion, the central bank of Bangladesh initiated 'School Banking Account' which offered charge free bank account and a very minimum opening balance. The study claimed school banking account as one of the financial inclusion strategies of Bangladesh Bank, which focused to literate the school going children about savings and modern banking facilities.

The aforesaid studies advocated the present scenario favoring the importance and increasing popularity of school banking. However, these papers did not predict the future of this initiative. Even, Scholars overlooked the future trend of any particular bank in the economy of a country specially Bangladesh. Research was conducted on different issues and cases of school banking but the previous studies did not consider a bank like DBBL as its case. The study on school banking is essential for a developing country like Bangladesh in order to enrich the existing literature as the prevailing study on school banking is scarce and could be found rarely. 


\section{Problem statement}

School banking is a magnificent initiative to take the students under the umbrella of banking services by which they can play role in savings and investments (Rahman, 2011). This type of banking provides an opportunity to the students for their financial inclusion by saving money in banks, (Mondal, Hossain \& Khan 2015) which are in turn invested in an economy. In this way, a vast number of students got involved themselves in banking system by the bless of school banking which was started in Bangladesh few years back (Sarker \& Foysal 2018). It grows savings tendency among students and educates them to manage their cash and balance (Hoque, 2017). For doing the same, it is to be mentioned that students need to have financial literacy (Norvilitis et al., 2006). For this, many banks have already introduced and some of them start launching school banking with special privileges and exciting features so that students can get educated about financial literacy and its substantial contribution. To make the initiative successful, there must have coordination and collaboration among stakeholders and actors. Instead of having significant advantage and bright prospect, most of the stakeholders are not considering the issue of school banking seriously. Because of lack of awareness, banks and students cannot realize the importance of school banking and thus it becomes difficult to make the school banking program successful. In addition, there are some misconception and misunderstanding about school banking in society which creates a barrier in the way of accomplishment of its goal. Therefore, Bangladesh is deprived of availing the full benefits of school banking. This study will opportune the students, banks and other stakeholders to be aware and knowledgeable about it. Many issues will be addressed by the study which will create an avenue for exploring the school banking concept, program and its contribution.

\section{Theoretical Concepts and Definitions}

\subsection{School Banking}

Simply school banking is banking for the students with prime objective of savings, deposit and withdrawal. In this type of banking, students of aging from 6 years to below 18 years can open a bank account with the consent of their guardians. Banks converts school banking account into regular savings account when a student turns into the age of 18 years (Sarker \& Foysal 2018). The account of this kind offers some lucrative advantages like free operating charge, high rate of interest, internet banking, cheque book and ATM card facility etc (Mondal, Hossain \& Khan 2015, Khan, Naim \& Begum 2017).

\subsection{History of School Banking in Bangladesh}

Mondal, Hossain \& Khan (2015) and Chowdhury (2019) opined that the school banking concept emerged in Bangladesh in the following ways;

In 1960: Before the liberation war, some banks along with Muslim bank introduced the concept of school banking at first. But the effort was ended within a short period of time with no fruitful result.

In 2003: AB Bank ltd. (formerly Arab Bangladesh Bank Ltd.) commenced the school banking service in Chottogram district at Sunshine Grammar School. AB bank Ltd. started the program unofficially and without any guidelines of Bangladesh Bank. Their effort was also concluded with disappointing results.

In 2010: Formal journey of school banking started by the direction and instruction of Bangladesh Bank. To promote and support school banking all over the country through all the scheduled banks and nonbank financial institutions, Bangladesh Bank appointed some lead banks for every district. In turn, the lead banks would be responsible for arranging school banking conference and fair and accountable for motivating other banks to open more school banking account etc.

In 2013: Bangladesh Bank issued a comprehensive policy guideline for smooth and clear operation of school banking. The guideline has highlighted that a student of 6 to below 18 age can have school banking account without any bank charge. The banks can now provide educational insurance to a school banking account holder in case of financial crisis of the student.

\subsection{Financial Inclusion}

Financial inclusion materializes when a large portion of underprivileged and low income people gets banking service easily and at reasonable cost (Leeladhar 2006, Dev 2006). More specifically, the broad aim of financial inclusion is to pick the unbanked people into the formal financial services so that they can save, pay and transact easily (Hannig \& Jansen 2010). For the students' financial inclusion, School Banking plays a vital role in Bangladesh. For doing this, Bangladesh Bank has introduced some contemporary school banking policy guidelines to amplify the financial inclusion process of the students.

\subsection{Child and Youth Finance International (CYFI) Award (2015)}

With the broad concept of 'financial inclusion drive', BB has undertaken various initiatives with the help of all scheduled banks of Bangladesh to accelerate the growth of school banking. For a remarkable effort in school banking, Bangladesh Bank won the CYFI award in London (Harmachi 2015, Hasan \& Zayed 2016). This award 
is a motivation for Bangladesh Bank that they have initiated a prosperous step to extend the boundary of financial inclusion in the country.

\section{School Banking: Bangladesh Bank Standpoint}

On 2nd November 2010, the Bangladesh Bank initiated students' financial inclusion policy by the 12th circular of Banking Regulation and Policy Department (BRPD) instructing all the scheduled banks to introduce banking services for the students attending school and colleges (Mondal, Hossain \& Khan 2015, Chowdhury 2019). As an aftereffect, most of the scheduled banks introduced school banking and the performance was worthy of remark. To increase the familiarity of this service and to ensure transparency and accountability, the Green Banking and CSR Department of Bangladesh Bank issued a policy guideline circular no. 07, on 28th October, 2013 (Chowdhury 2019). As per the guideline, the students aged between 6 to below 18 is now eligible for school banking with the consent of parents or legal guardian with minimum initial deposit of Taka 100. The KYC profile of the account holder and operator is properly maintained at the time of opening the account. Accounts holders are allowed to deposit and withdraw Tk 2,000 (Tk.5000 on guardian's request) with the consent of the parents. This account is free from banking charges but it contains government fee, ATM card issue and renewal fee. Bangladesh Bank has also motivated the scheduled banks to open a separate school banking corner or desk in every branch or department and instructed to provide educational insurance to the students in financial difficulty to bear the educational expenses. Under this guideline, all the banks need to submit the progress report of school banking to BB on quarterly basis.

Table 1: Overview of School Banking Account and Deposit: Bangladesh Bank Perspective

\begin{tabular}{|c|c|c|c|c|c|c|}
\hline \multirow{3}{*}{ Year } & \multicolumn{6}{|c|}{ Type of Banks } \\
\hline & \multicolumn{2}{|c|}{$\begin{array}{l}\text { State Owned Commercial } \\
\text { Banks (SCBs) }\end{array}$} & \multicolumn{2}{|c|}{$\begin{array}{lll}\begin{array}{l}\text { Private } \\
(\mathrm{PCBs})\end{array} & \text { Commercial } & \text { Banks } \\
\end{array}$} & \multicolumn{2}{|c|}{$\begin{array}{l}\text { Foreign Commercial } \\
\text { (FCBs) }\end{array}$} \\
\hline & No. of $\mathrm{A} / \mathrm{Cs}$ & $\begin{array}{l}\text { Deposit } \\
\text { (Million Taka) }\end{array}$ & No. of $\mathrm{A} / \mathrm{Cs}$ & $\begin{array}{l}\text { Deposit } \\
\text { (Million Taka) }\end{array}$ & No. of $\mathrm{A} / \mathrm{Cs}$ & $\begin{array}{l}\text { Deposit } \\
\text { (Million Taka) }\end{array}$ \\
\hline 2014 & 101468 & 50.4 & 430284 & 3935.3 & 1210 & 17.4 \\
\hline 2015 & 206856 & 337.4 & 556233 & 6320.9 & 1224 & 14.3 \\
\hline 2016 & 322761 & 948.8 & 650378 & 7585.1 & 1462 & 74.1 \\
\hline 2017 & 408100 & 1600 & 793599 & 9360 & 1871 & 100 \\
\hline 2018 & 436001 & 1800 & 973618 & 12000 & 2260 & 140 \\
\hline
\end{tabular}

Source: Annual Report (2014-2018), Financial Inclusion Department, Bangladesh Bank

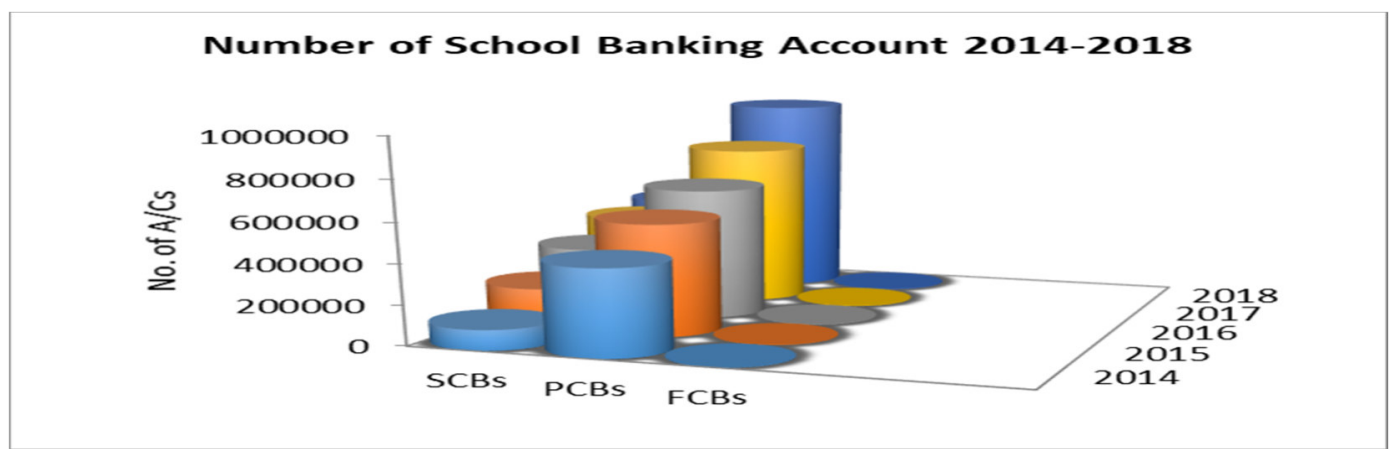

Graph 1: School Banking Account of Different Types of Banks

The above graph shows the year wise number of school banking accounts of different types of banks which are recorded and published by BB. Overall, there found an upward trend in school banking account opening among banks of different kinds. Between 2014 to 2018, the number of accounts went up by about 3.35 lacs of SCBs, approximately 5.43 lacs of PCBs and almost 1.00 thousand of FCBs. The data regarding SCBs showed that the number of school banking account was gradually increasing from approximately 01 lac in 2014 to about 4.36 lacs in 2018. The performance of PCBs is noticeable among the different types of banks regulated under BB with a rapid increase from about 4.30 lacs in 2014 to approximately 9.73 lacs in 2018. The performance of FCBs is sluggish. The number of school banking accounts rose to approximately 2000 in 2018 from 1000 in 2014. 


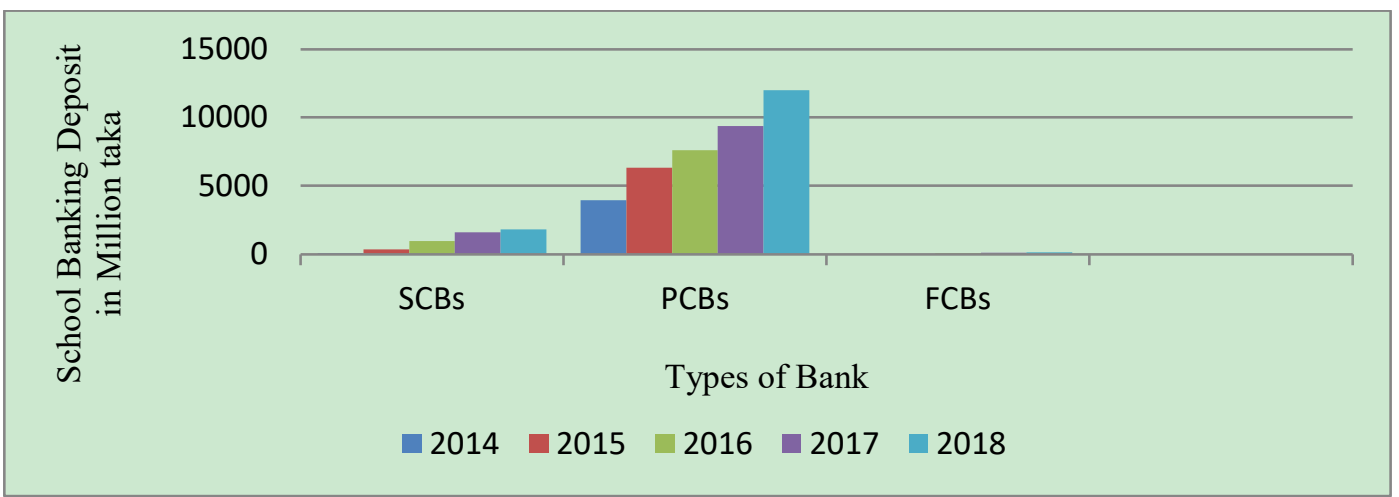

Graph 2: School Banking Deposit of Different Types of Banks (2014-2018)

The above chart depicts the year wise contribution of school banking deposit balance of SCBs, PCBs and FCBs between 2014 to 2018, units measured in million Taka. Deposit generation through school banking tended to go up during the given year in banks. There was a dramatic increase in school banking deposit of the PCBs among other types of Banks. Over the last 05 years, the deposit of PCBs was increased by approximately 8000 million taka. Turning to the other side, the lowest amount of deposit was collected by FCBs, which began with about 17 million in 2014 and reached to 140 million in 2018. Even, FCBs faced a decrease in deposit balance from 17.4 million to 14.30 million between the year 2014 and 2015. But FCBs showed a nearly consistent positive growth in the collection of the school banking deposit balance from 2016 to 2018. In the same way, the deposit of SCBs was having an upward trend from almost 50 million in 2014 to 1800 million in 2018 which was increased by about 1750 million over the 05 years. SCBs and PCBs are gradually increasing the number of school banking account and deposit balance but the growth of FCBs school banking is dissatisfactory.

\section{School Banking Account: DBBL Perspective}

To make the young generation acquaintance with the updated and modern banking services, Dutch-Bangla Bank Ltd., a scheduled joint venture commercial bank in Bangladesh inaugurated school banking account with the title "DBBL School Savers Account" on 3rd March, 2011. Bangladeshi students aged below 18 can open this interest paying savings account with opening deposit of minimum BDT 100/- only. Students can take care of their fund management through electronic and online banking as per their convenient time (24/7 access) via the usage of ATM and Internet. DBBL offers charge free DBBL Nexux Debit/ATM Card and SMS alert service to the students.

\section{Research Methods}

The data were collected from the secondary sources though the existing data on school banking were rare. The data which were considered for the description and analysis, derived mainly from the published annual reports of Bangladesh Bank (BB) and Dutch Bangla Bank Ltd. (DBBL) and Bangladesh Bureau of Educational Information and Statistics (BANBEIS) in between the year 2014 to 2018. Likewise, the data were also collected from other secondary sources such as reputed newspapers, journals, websites and articles. Descriptive statistics, SPSS trend analysis and Microsoft office excel were used for the analysis, interpretation and discussion of the collected data. Different types of graphs like line graph, bar graph, area graph etc. were also employed for the presentation of data.

\section{Data Analysis and Discussion}

8.1 Descriptive Analysis

In this section, the study analyzed the collected data of secondary sources for explaining the contribution of Dutch Bangla Bank Ltd. (DBBL) from various perspectives. Even, the data were presented graphically for the better understanding of the readers

Table 2: Contribution of DBBL School Banking Account and Deposit towards Private Commercial Banks (PCBs)

\begin{tabular}{|c|c|c|c|c|c|c|}
\hline \multirow[b]{2}{*}{ Year } & \multicolumn{2}{|c|}{ School Banking Account } & \multirow{2}{*}{$\begin{array}{lr}\text { Contribution of DBBL } \\
\text { School } & \text { Banking } \\
\text { Account } & \text { towards } \\
\text { PCBs (\%) } & \end{array}$} & \multicolumn{2}{|c|}{ School Banking Deposit } & \multirow{2}{*}{$\begin{array}{lr}\text { Contribution } & \text { of } \\
\text { DBBL } & \text { School } \\
\text { Banking } & \text { Deposit } \\
\text { towards PCBs }(\%)\end{array}$} \\
\hline & PCBs & DBBL & & $\begin{array}{l}\text { PCBs } \\
\text { (Million } \\
\text { Taka) }\end{array}$ & $\begin{array}{l}\text { DBBL } \\
\text { (Million } \\
\text { Taka) }\end{array}$ & \\
\hline 2015 & 556233 & 98,328 & 17.68 & 6320.9 & 2624.7 & 41.52 \\
\hline 2016 & 650378 & 123,172 & 18.94 & 7585.1 & 3429.9 & 45.22 \\
\hline 2017 & 793599 & 171,362 & 21.59 & 9360 & 4067.1 & 43.45 \\
\hline 2018 & 973618 & 307,989 & 31.63 & 12000 & 4520.6 & 37.67 \\
\hline
\end{tabular}

Source: Annual Report of Bangladesh Bank \& Dutch-Bangla Bank Limited (2015-2018) 


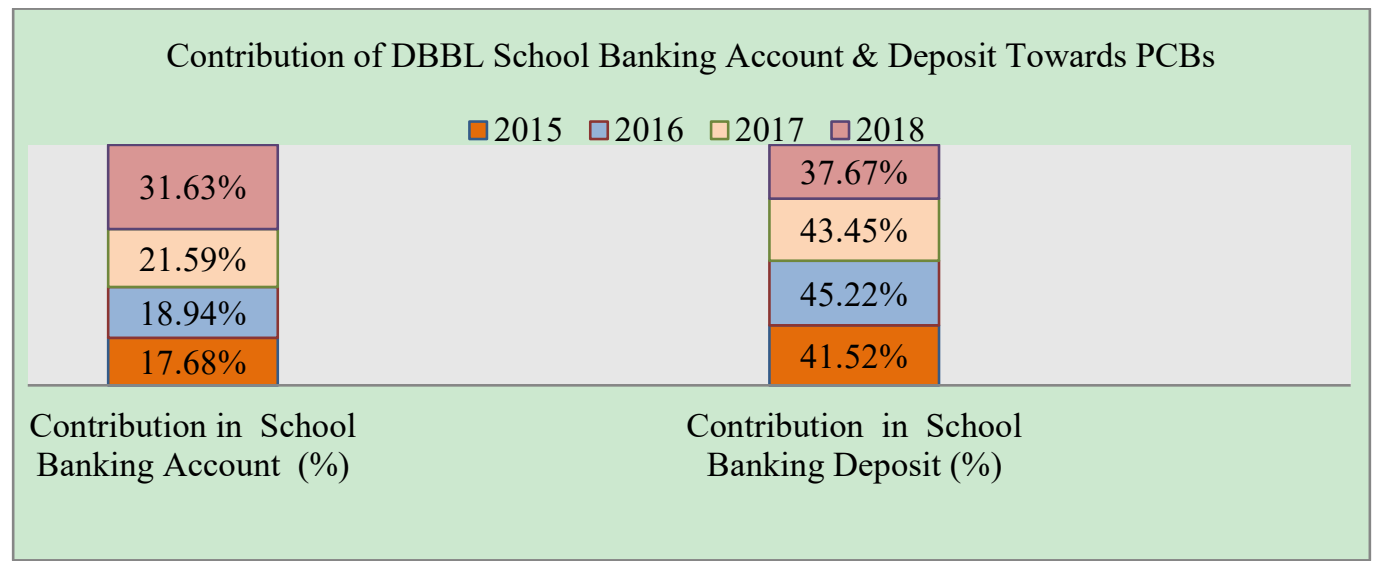

Graph 3: Yearly contribution of DBBL School Banking Account and Deposit towards PCBs (2015-2018)

The graph shows a comparison of contribution of DBBL towards PCBs during the years 2015-2018 in terms of school banking account opening and deposit balance. Overall, the DBBL student savers accounts have a consistent positive growth though initially the deposit balance went up gradually for the year 2015 but then felt back slowly over the last 04 years. In the first column of the graph, the DBBLSchool savers account rose from $17.68 \%$ in 2015 to $31.63 \%$ in 2018 . Besides, the second column illustrated the percentage of deposit balance contribution of DBBL compared to PCBs. There was a consistent increase in deposit balance of DBBL in between 2015 to 2016 . But the deposit was alarmingly decreased from $43.45 \%$ in 2017 to $37.67 \%$ in 2018 respectively.

Table 3: Comparison of DBBL Student Savers Account with Total Students of Bangladesh

\begin{tabular}{|c|c|c|c|c|c|c|c|}
\hline \multirow[b]{3}{*}{ Year } & \multicolumn{4}{|c|}{ No. of Students (Focused Age: 6 to below 18 ) } & \multirow{3}{*}{$\begin{array}{l}\text { Total } \\
\text { Students } \\
\text { (Focused } \\
\text { Age: } 6 \text { to } \\
\text { below 18) }\end{array}$} & \multirow{3}{*}{$\begin{array}{l}\text { DBBL } \\
\text { Student } \\
\text { Savers } \\
\text { Account }\end{array}$} & \multirow{3}{*}{$\begin{array}{l}\text { Students } \\
\text { Brought Under } \\
\text { DBBL School } \\
\text { Banking }(\%)\end{array}$} \\
\hline & \multirow[b]{2}{*}{ Primary } & \multirow[b]{2}{*}{ Secondary } & \multicolumn{2}{|c|}{ College } & & & \\
\hline & & & $\begin{array}{l}\text { School } \\
\text { and } \\
\text { College }\end{array}$ & $\begin{array}{l}\text { Higher } \\
\text { Secondary } \\
\text { College }\end{array}$ & & & \\
\hline 2015 & 19067761 & 9743072 & 272106 & 355061 & 29438000 & 98328 & 0.33 \\
\hline 2016 & 18602988 & 10107089 & 293046 & 348188 & 29351311 & 123172 & 0.42 \\
\hline 2017 & 17251350 & 10330695 & 307240 & 342584 & 28231869 & 171362 & 0.61 \\
\hline 2018 & 17338100 & 10475100 & 353173 & 388122 & 28554495 & 307989 & 1.08 \\
\hline
\end{tabular}

Source: Bangladesh Bureau of Educational Information and Statistics (BANBEIS) \& Annual Report of DutchBangla Bank Limited (2015-2018)

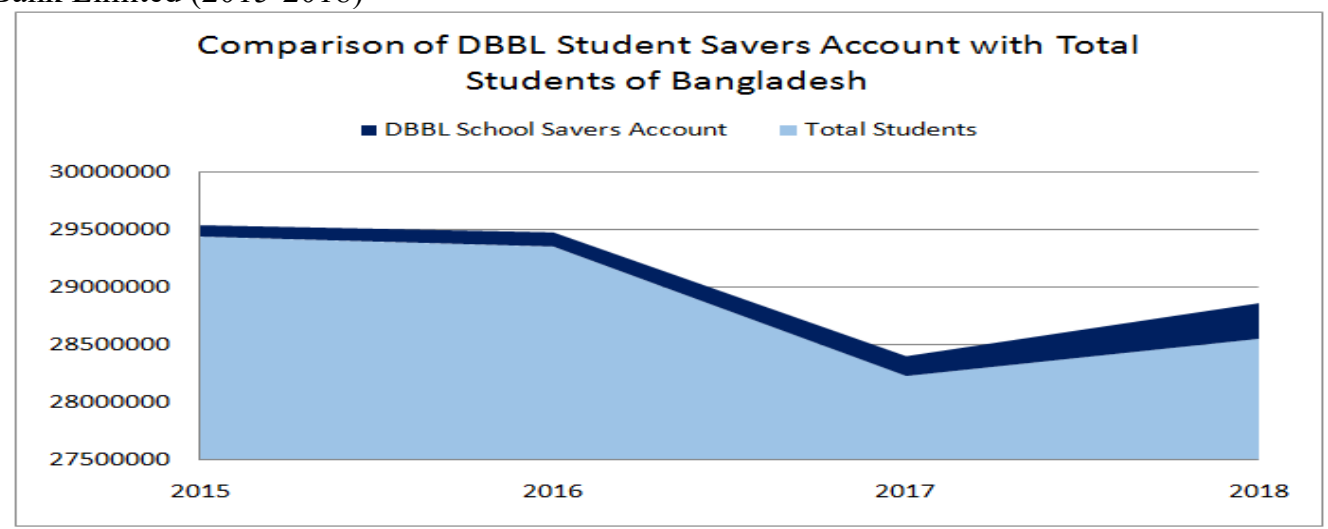

Graph 4: Comparison of DBBL Student Savers Account with Total Students of Bangladesh (Students' age 6 to Below 18)

The above graph compares between the numeral of students having the DBBL student savers accounts and the year wise total number of students in Bangladesh aged between 6 years to below 18 years studying in government enlisted primary schools, secondary schools and higher secondary colleges. The bottom part of the graph indicates the total of students in the country and the upper area indicates the number of school banking accounts of DBBL. In between 2015 and 2017, DBBL had included insignificant number of students into their school banking scheme. But in 2018, the bank covered a considerable inclusion of the students in its banking services amounting of nearly $1.08 \%$ of the total students where it was $0.33 \%$ in $2015,0.42 \%$ in 2016 and $0.61 \%$ in 2017 respectively. 
Table 4: DBBL's Promotion of School Banking through Conference/Literacy Campaign (2015-2018)

\begin{tabular}{|c|c|c|c|c|c|c|}
\hline \multirow[b]{3}{*}{ Year } & \multicolumn{4}{|c|}{ No. of Educational Institution } & \multirow{3}{*}{$\begin{array}{l}\text { Total } \\
\text { Institution } \\
\text { (Focused Age: } \\
6 \text { to below 18) }\end{array}$} & \multirow{3}{*}{$\begin{array}{l}\text { DBBL Conference } \\
\text { (C) } \\
\text { Campaign (LC) }\end{array}$} \\
\hline & \multirow[b]{2}{*}{ Primary } & \multirow[b]{2}{*}{ Secondary } & \multicolumn{2}{|c|}{ College } & & \\
\hline & & & $\begin{array}{l}\text { School and } \\
\text { College }\end{array}$ & $\begin{array}{l}\text { Higher Secondary } \\
\text { College }\end{array}$ & & \\
\hline 2015 & 122176 & 20297 & 1008 & 1346 & 144827 & $03(\mathrm{C})$ \\
\hline 2016 & 126,615 & 19847 & 1047 & 1372 & 148881 & $61(\mathrm{LC})$ \\
\hline 2017 & 133901 & 19848 & 1234 & 1323 & 156306 & 696 (LC) \\
\hline 2018 & 134147 & 20465 & 1268 & 1335 & 157215 & $514(\mathrm{LC})$ \\
\hline
\end{tabular}

Source: Bangladesh Bureau of Educational Information and Statistics (BANBEIS) \& Annual Report of DutchBangla Bank Limited (2015-2018).

The above table described the promotional endeavor of school banking with respect to the total number of educational institutions in Bangladesh enlightening the students of 6 years to below 18 years in general between 2015-2018. In 2015, DBBL arranged just three conferences to promote school banking which is very negligible in respect to the total number of educational institutions. DBBL has accelerated its effort in 2017 by 696 number of literacy campaigns all over the country. In contrast, the number of literacy campaign was only 61 in 2016 . Besides, there found a sluggish trend of DBBL in 2018 compared to the immediate last year by arranging financial literacy campaigns in 514 educational institutions. The lack of active effort by DBBL along with all the actors is responsible for the downward trend in undertaking the campaigns in educational institutions.

Table 5: Performance of DBBL in Tuition Fee collection of Educational Institutions through School Savers Account

\begin{tabular}{|c|c|c|c|}
\hline Year & $\begin{array}{c}\text { No. of Educational } \\
\text { Institutions (Focused } \\
\text { Age: 6 to below 18) }\end{array}$ & $\begin{array}{c}\text { Educational Institutions using DBBL } \\
\text { School Banking for Collecting their Tuition } \\
\text { Fees }\end{array}$ & $\begin{array}{c}\text { Covered Institutions by } \\
\text { DBBL (\%) }\end{array}$ \\
\hline 2015 & 144827 & 8 & 0.01 \\
\hline 2016 & 148881 & 9 & 0.01 \\
\hline 2017 & 156306 & 9 & 0.01 \\
\hline 2018 & 157215 & 9 & 0.01 \\
\hline
\end{tabular}

Source: (BANBEIS) \& Annual Report of Dutch Bangla Bank Limited (2015-2018)

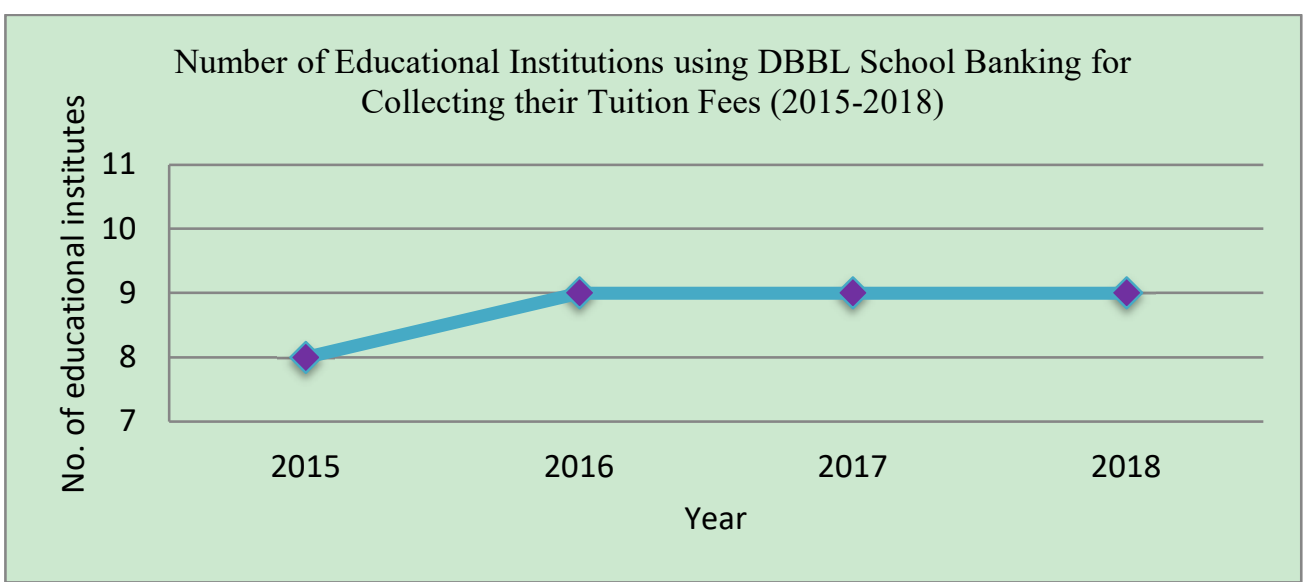

Graph 5: Performance of DBBL in terms of Tuition Fee collection of Educational Institutions

The above graph shows the performance of DBBL in collecting tuition fee of educational institutions from 2015 to 2018. DBBL had a poor performance in this regard. In 2015, DBBL collected tuition fees on behalf of 8 institutions. Furthermore, the tuition fee of 9 educational institutions was collected by DBBL for 2016, 2017 and 2018 where DBBL failed to increase the number of educational institutions during the years. If the performance is converted into percentage against the total numbers of educational institutions in Bangladesh, DBBL is slow footed and have only $0.01 \%$ educational institutions coverage throughout 2015 to 2018 .

\subsection{Trend Analysis}

In this part, firstly the study presented the contribution of DBBL in school banking initiative for the last 04 years (2015-2018) in terms of account and deposit (table 6). Then, secondly, the previous years' data (2015-2018) were analyzed to predict the estimated trend of school banking for the following two years 2019 and 2020 (table 7). As the annual report of DBBL for the year 2019 is not publish yet, the study needs to forecast the future of school banking for the year 2019 along with 2020. For doing the same, the authors employed SPSS trend analysis to 
summarize, analyze and interpret the data.

Table 6: Account and Deposit of DBBL School Savers Account (2015-2018)

\begin{tabular}{|l|l|l|l|l|}
\hline Year & $\begin{array}{l}\text { Number of School } \\
\text { Savers Account }\end{array}$ & $\begin{array}{l}\text { Increase in DBBL School } \\
\text { Savers Account over last year }\end{array}$ & $\begin{array}{l}\text { Deposit } \\
\text { (Million Taka) }\end{array}$ & $\begin{array}{l}\text { Increase in Deposit over } \\
\text { last year (in Million Taka) }\end{array}$ \\
\hline 2015 & 98,328 & - & 2624.7 & - \\
\hline 2016 & 123,172 & 24,844 & 3429.9 & 805.2 \\
\hline 2017 & 171,362 & 48,190 & 4067.1 & 637.2 \\
\hline 2018 & 307,989 & 136,627 & 4520.6 & 453.5 \\
\hline
\end{tabular}

Source: Annual Report (2015-2018), Dutch-Bangla Bank Limited

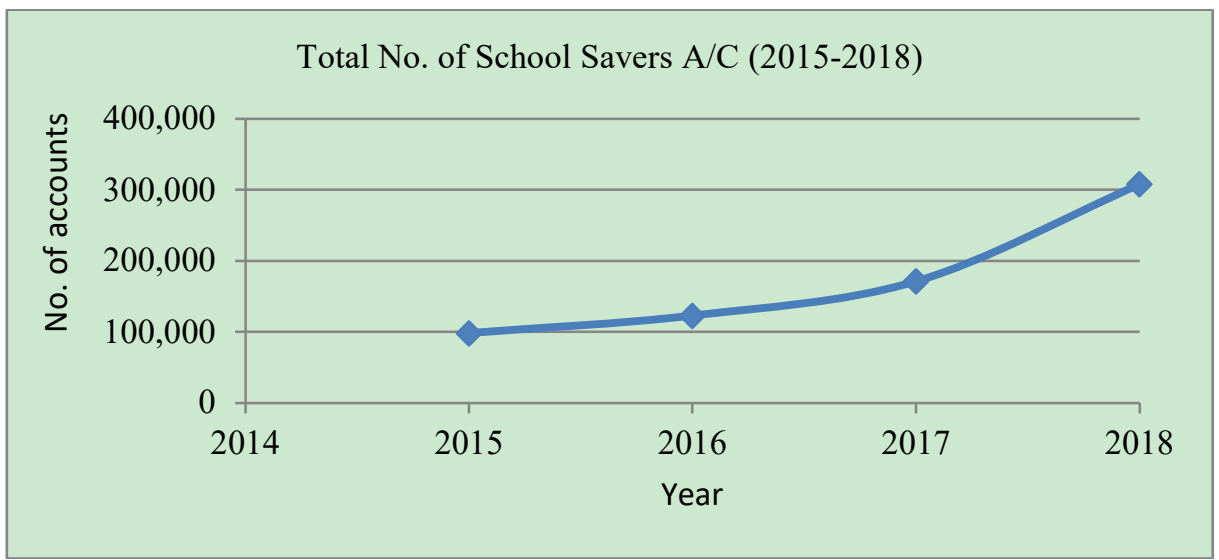

Graph 6: No. of DBBL School Savers Account (2015-2018)

The line graph displays the year wise number of school banking accounts of DBBL from the year of 2015 to 2018. There found an upward trend in number of DBBL school savers account over the 04 given consecutive years. The study portrayed a rapid increase in school banking account in 2018 while the least performance was in 2015. There was a slow rise from about1.00 lac number of accounts in 2015 to approximately 1.70 lac accounts in 2017 . After that, between 2015 and 2018, The number of account opening was increased by almost 2.09 lac. DBBL employed its remarkable efforts to bring a significant increase in account opening in recent years. The graph depicts that the bank's initiative does well and works effectively to rise the number of school banking accounts. This bank may have a great contribution to flourish the concept of banking for students in Bangladesh if it keeps continuing to undertake initiatives alike in future.

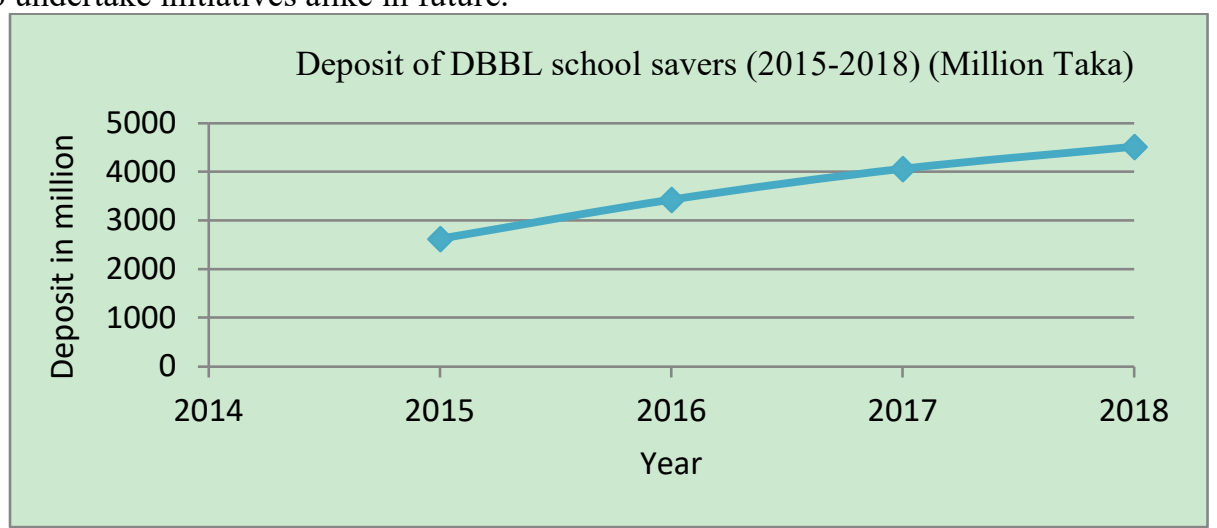

Graph 7: Deposit of DBBL School Savers Account (2015-2018).

The above graph shows an upward trend over the given period where units are measured in millions. There found a slow, gradual and consistent growth from approximate 2600 million in 2015 to above 4500 million in 2018. The above graph explained that DBBL has given a consistent concentration on school banking and tried to promote their school banking scheme to increase the deposit balance. Still the bank has a lot of tools and techniques to apply to explore the emerging prospect of school banking and to contribute for the economy in the same manner. 
Table 7: Trend Analysis of Account and Deposit of DBBL School Savers Account for 2019 and 2020

\begin{tabular}{|l|l|l|}
\hline Year & Total No. of School Savers A/C & Total Deposit (Million Taka) \\
\hline 2015 & 98,328 & 2624.7 \\
\hline 2016 & 123,172 & 3429.9 \\
\hline 2017 & 171,362 & 4067.1 \\
\hline 2018 & 307,989 & 4520.6 \\
\hline 2019 & 344506 & 4977.29 \\
\hline 2020 & 412223.3 & 5503.976 \\
\hline
\end{tabular}

This study predicts the future trend of DBBL school banking savers accounts and deposit for the year 2019 and 2020. It is to be noted that the authors forecast the possible performance of DBBL by trend analysis for the year 2019 along with the year 2020 as the annual report of DBBL for the year 2019 has not been published yet. It will take the middle of 2020 to publish the annual report of the said bank. Hence, to predict the year 2020, it is required to know the trend of 2019 first and thus the authors analyzed the future of the consecutive 02 years, 2019 and 2020.

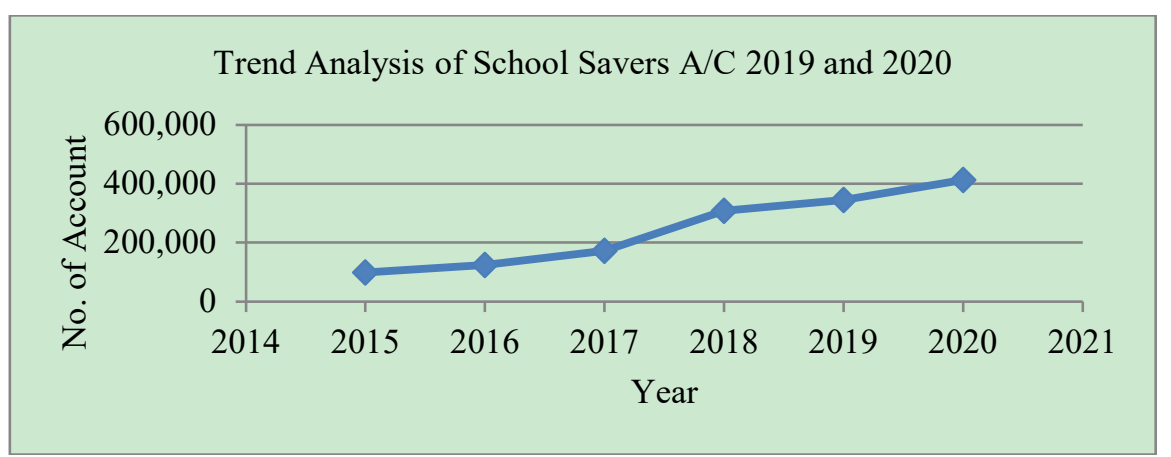

Graph 8: Trend Analysis of No. of School Savers Account of DBBL

By using the existing data from 2015 to 2018, The chart predicts that DBBL school savers account will have a gradual growth over the two years, 2019-2020. There will be an upward trend from approximately 3.50 lacs number of accounts in 2019 to over 4.00 number of accounts in 2020. As the policy and strategies for school banking account opening of DBBL has remained unchanged from the inception of the school banking programs, so the patterned trend shows the same type of growth prediction in the consecutive two years. Therefore, the techniques must be updated and revised to attract more students under the financial inclusion umbrella offered by the bank. Moreover, all the stakeholders including government and Bangladesh bank need to work together collaboratively to bring and ensure the bright prospect of school banking in Bangladesh.

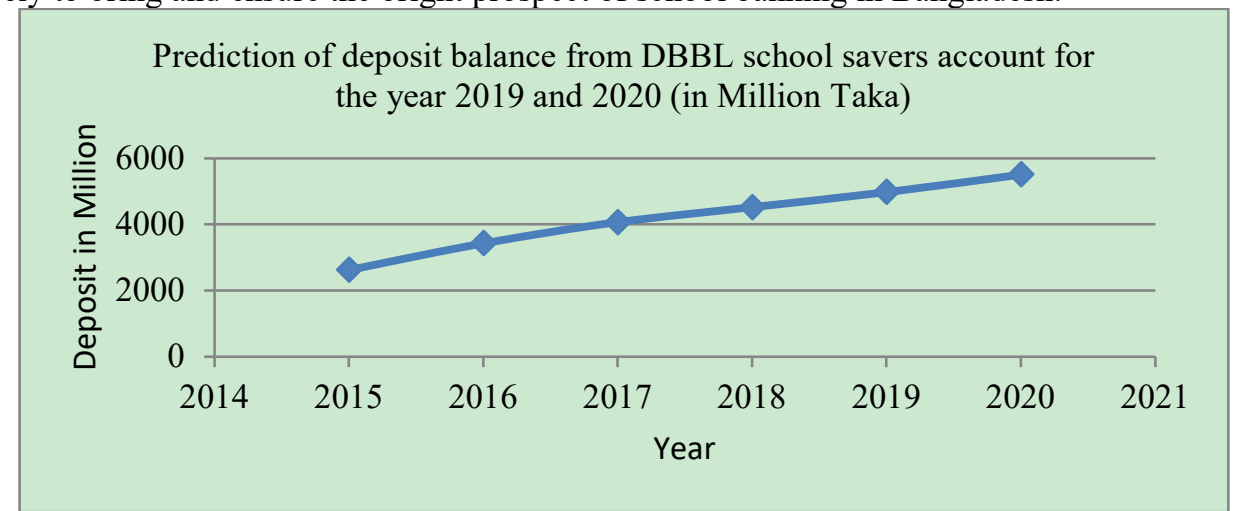

Graph 9: Trend Analysis of Deposit from DBBL School Savers Account (2019 and 2020)

The study uses the existing data from 2015 to 2018 about deposit of DBBL and then forecasts the deposit trend in the year of 2019 and 2020, units are measured in million. The graph above indicates a slow and steady increasing trend over the given period. The estimated deposit for the year 2019 and 2020 can be 4977.29 million and 5503.976 million respectively. From the very beginning, the deposit comes from DBBL school savers accounts does not contribute significantly because the students cannot save as much money as compared to other types of account holders. Even many guardians discourage the students to open bank account and do transaction with banks. Hence the collected deposit through school banking does not constitute much. DBBL can initiate more awareness and promotional programs to accelerate the growth of its school banking accounts in future.

\section{Specific Findings}

i. According to Bangladesh Bank annual report (2014-2018), Private Commercial Banks (PCBs) are 
more dedicated towards the school banking account and deposit balance among the different types of banks.

ii. The number of school banking account of DBBL is gradually increasing and having an estimated future growth.

iii. DBBL contributes on an average 40\% deposit balance in between 2015 to 2018 to total PCBs school banking deposit. In terms of deposit collection, DBBL is at the peak of all scheduled private commercial banks in Bangladesh. In future, it is expected and predicted that the private commercial banks like DBBL will contribute immensely in school banking program of Bangladesh.

iv. In 2018, the total number of students (aged between 6years to below 18years) is 2 crores and 85 lakhs (rounded) and by that time of the year DBBL has 3 lakhs (rounded) school banking account. Nearly $1.08 \%$ students of the total in students are the school savers account holder of DBBL in 2018.

v. DBBL should arrange more financial literacy campaign across the country. In 2017 it arranged 696 literacy campaign where in 2018 the number of literacy campaigned dropped to 514.

vi. For the last three consecutive years of 2016 to 2018, DBBL is collecting tuition fee for solely 09 educational institutions. Still there are opportunities to explore by arranging agreement with educational institutions to collect tuition fees.

\section{Recommendations}

i. DBBL should permanently arrange a separate and dedicated desk for school banking activities in all of its branches to instigate the students to come to the bank and lessen the fear of banking antipathy.

ii. DBBL can arrange a mini bank booth in front of different educational institution on a particular day on each month to motivate the students about school banking. The bank can also take deposit and allow withdrawal of money on the spot to facilitate the banking activity among the students. By this style of banking, students don't need to schedule their time for school banking of their kids.

iii. DBBL needs to motivate educational institutions to collect their monthly tuition fees through DBBL School banking account on a regular basis.

iv. DBBL may focus and promote its "School Savers Account" what they do for their regular banking products and services. Hence, DBBL should keep up their effort and promotional strategies to include a large number of students into their school savers account policy.

v. If parents make their kids aware of school banking and the educational institutions support their students' savings practice by school banking, then the contribution of school banking towards the economy will definitely increase.

vi. DBBL management can be interested in arranging more financial literacy campaign and awareness program for all the stakeholders across the country.

vii. On opening of a school banking account, DBBL can offer gifts like reading and writing materials or school bag or mug etc. to the account holder containing the logo and slogan of the bank. This step not only influences the students to open a student banking account but also promotes school banking scheme of DBBL to the general public.

\section{Implication}

The study provides the general understanding of school banking and its overall scenario in Bangladesh. In addition, the report shows how school banking contributes in financial inclusion of the students and thus plays a key role in an economy. Likewise, the paper also helps to notify the concerned stakeholders about current necessity and emerging prospects of school banking so that they can undertake the best possible initiatives and timely action for the smooth improvement of it. Similarly, the relevant stakeholders and other concerned authorities can take help from this paper to formulate strategic plans for ensuring the rapid growth and successful implementation of school banking programs. In the same way, external people can get an insight and knowledge about school banking as well as its prospects and contribution towards student's involvement in banking system. Furthermore, the findings of the study recommend some unique ways to flourish school banking as a new idea for student's financial inclusion. Thus, the study may contribute to enrich the existing literature in many possible means. Finally, it is expected that the scholar will feel interested to study in this field in future by getting identified future research direction from this study.

\section{Limitations and future research directions}

There were found some common limitations of this study that can be treated as future research directions for the researchers. Firstly, the data were collected from secondary sources only. However, the collection, analysis and presentation of fresh data can contribute greatly to this study. Secondly, the consecutive four years' (2015-2018), sometimes five years (2014-018) annual data of Banglaesh Bank, DBBL and BANBEIS only were collected and considered for description and analysis which were very limited and few in numbers. But the insertion and use of 
fresh data from primary sources even more data from different existing sources would give more realistic and accurate result and interpretation. Hence, the scholar can use more data from various authentic sources for conducting study in this area to present and validate a clear understanding, findings, interpretations and recommendations. Thirdly, this paper considered DBBL as a case and concentrated on this bank's contribution in students' financial inclusion and hence the key role played by other banks in this regard was somehow ignored in its findings. Therefore, future scholars are advised to conduct more research on school banking by considering the contribution of other banks and their collaborative impact in an economy of a nation like Bangladesh. Finally, the prospective performance of DBBL for the year 2019 and 2020 is the outcome of an educated guess by applying trend analysis method. If any deviation occurs after publishing the annual report of DBBL, then scholars can come forward and conduct further research on the topic.

\section{Conclusion}

Financial knowledge should not be limited within the limit of adults but it needs to be extended among the kids too as they are the mainstay of the future. The savings tendency and money management skill should be taught at an early age to flourish the afterlife savings practice of a student. In order to attain a prosperous economy and increase financial inclusion, Bangladesh Bank (BB) initiated school banking concept to be operated by all the scheduled banks and non-bank intuitions in Bangladesh. From the outset of school banking inauguration, Bangladesh bank (BB) is continuously issuing policy and guidelines to support and promote school banking. Commercial banks are the pioneers of school banking that are contributing the massive amount school banking account and deposit balance. DBBL holds the record amount of deposit balance from school banking scheme among all the private commercial banks (PCBs). For the time being, DBBL should boost its promotional exertion to proliferate the number of school banking accounts alongside deposit. School banking is a policy aspiration to enlarge the financial inclusion in Bangladesh which can contribute an economy immensely. If banks treat this school banking activity as like their regular banking product and services, the outcome from this account can be desponded. In spite of providing a charge free account, Banks need to pay profit on the school banking deposit. Hence, all the banks can consider this policy as a part of their Corporate Social Responsibility (CSR) activity to fetch more students into banking coverage. Even the banks can invest in this initiative for future as the students can be their clients of tomorrow. The idiosyncratic contribution of a student from school banking deposit apparently low but the accumulated deposit of all the school goers can have a tremendous contribution towards the economic development and finally ameliorate financial inclusion in Bangladesh.

\section{Funding: No funds received for this study}

\section{References}

Bangladesh Bank, Annual Report, Green banking and CSR Department, Financial Inclusion Wing, Dhaka: June 2014 to June 2018 Available at: https://www.bb.org.bd/.

Bangladesh Bureau of Educational Information and Statistics (BANBEIS).Available at: http://www.banbeis.gov.bd/.

Bowman, M.E., 1922. The School Savings Bank. The Elementary School Journal, 23(1), pp.56-67.

Beverly, S.G. and Burkhalter, E.K., 2005. Improving the financial literacy and practices of youths. Children \& Schools, 27(2), p.121.

Chowdhury M. M. H., 2019. School banking: Ensuring financial inclusion since childhood. The Financial Express. Available at: https://www.thefinancialexpress.com.bd/views/school-banking-ensuring-financial- inclusionsince-childhood-1563374228

Dutch-Bangla Bank Limited, Annual Report 2015 to 2018. Available at: https:/www.dutchbanglabank.com/

Dev, S.M., 2006. Financial inclusion: Issues and challenges. Economic and political weekly, pp.4310-4313.

Harmachi A. R., 2015. Bangladesh wins award for school banking in London. bdnews24.com. Available at: https://bdnews24.com/economy/2015/12/10/bangladesh-wins-award-for-school- banking in- london.

Hasan M. A., Zayed K. A. A., 2016. Exploring opportunities: School banking initiatives. The Independent. Available at: http://www.theindependentbd.com/arcprint/details/40917/2016-04-18

Hasan M., 2018. School banking gaining momentum. Dhaka Tribune. Available at: https://www.dhakatribune.com/business/2018/12/10/school-banking-gaining-momentum.

Hoque M. M., 2017. School banking: Welcoming children to the financial world. The Financial Express. Available at:https://www.thefinancialexpress.com.bd/views/school-banking-welcoming-children-to-the-financialworld-1513351084

Hossain, S.M., Islam, S.N., Hossain, M.N., Hossain, M.M., Yesmin, R. and Mohiuddin, G., Financial Inclusion Initiatives of Bangladesh Bank: Evaluation and Challenges. Banking Research Series 2015, p.200.

Hannig, A. and Jansen, S., 2010. Financial inclusion and financial stability: Current policy issues.

Iraj S., 2018. School Banking. The Independent. Available 
at:http://www.theindependentbd.com/magazine/details/157503/School-Banking-

Islam M. S., 2019. School banking for inclusive growth. The Financial Express. Available at: https://www.academia.edu/31657111/School_banking_for_inclusive_growth.

Khan, M. T. A.; Naim, M. J., \& Begum, K., 2017. An Evaluation of School Banking Practices in Bangladesh- A Scope to make financial inclusion. The Cost and Management, 45(4), pp.13-18.

Leeladhar, V., 2006. Taking banking services to the common man-financial inclusion. Reserve Bank of India Bulletin, 60(1), pp.73-77.

Ministry of Education (MoED). Available at: https://moedu.gov.bd/

Mondal, U., Hossain, M.S. and Khan, M.A.M., 2015. School banking: a new idea of banking operation in Bangladesh. International Journal of Science and Research, 4(11), pp.1926-1931.

Norvilitis, J.M., Merwin, M.M., Osberg, T.M., Roehling, P.V., Young, P. and Kamas, M.M., 2006. Personality factors, money attitudes, financial knowledge, and credit-card debt in college students 1 . Journal of applied social psychology, 36(6), pp.1395-1413.

Rahman, S., 2011. A new era of school banking. The Daily Star. Available at: https://www.thedailystar.net/newsdetail-185235

Rana, M.M., Kalam, A., Halimuzzaman, M., Kalam, A. and Halimuzzaman, M., 2012. Corporate social responsibility (csr) of dutch-bangla bank limited: A case study. Bangladesh Research Publication Journal, 7(3), pp.241-247.

Sarker, S. A., \& Foysal, T. Y., 2018. Contemporary Financial services in Bangladesh: Case Study on School Banking. The Cost and Management, 46(2), pp. 37-44. 